\title{
Development and validation of UV spectrophotometric method for quantitative estimation of Promethazine $\mathrm{HCl}$ in phosphate buffer saline $\mathrm{pH} 7.4$
}

\author{
Dwi Nurahmanto \\ Laboratory of Pharmaceutical, Faculty of Pharmacy, Jember University, East Java, Indonesia
}

\begin{abstract}
A new, sensitive, rapid, simple, specific and economical procedure has been developed for determination Promethazine $\mathrm{HCl}$ in phosphate buffer saline $\mathrm{pH}$ 7.4. The purpose of this analytical validation procedure is to determine a process of assessment and to validate it by laboratory experiments to prove that the method meets the minimum standard for laboratory use. This analytical method for the determination of Promethazine $\mathrm{HCl}$ in phosphate buffer saline $\mathrm{pH} 7.4$ can be used to estimate the amount of promethazine $\mathrm{HCl}$ penetrated and dissolved in the blood vessels in vitro by penetration study. The method is based on the ultraviolet light absorbance at $251 \mathrm{~nm}$ which is the maximum wavelength of the concerned drug. This method can be succesfully applied for determination of drug in phosphate buffer saline $\mathrm{pH}$ 7.4. The results of the analysis have been validated statistically and by recovery studies.
\end{abstract}

Key Words: Promethazine HCl, PBS pH 7.4, Validation, Spectrophotometer UV

\section{INTRODUCTION}

Promethazine-hydrochloride is the generic name of (2RS)$\mathrm{N}$, N-dimethyl-1-(10H-phenothiazin-10-yl) propan-2amine hydrochloride. It is a first generation $\mathrm{H} 1$ antagonist acceptor, antihistamine and antiemetic medication. Promethazine $\mathrm{HCl}$ is the first choice in the case of morning sickness in the UK (Anonymous, 2007). Another effect of the drug is its powerful sedativeness, although it is rarely used specifically for this purpose. Having a $\mathrm{pKa}$ of 9.1, Promethazine $\mathrm{HCl}$ is a weak base (Alam et al., 2007). The drug is available as a white-yellowish crystalline, odorless powder form. Oxidation resulted in color change to blue that occurs slowly when it is exposed to air. Promethazine $\mathrm{HCl}$ salt is very easily soluble in water and soluble in alcohol (Saif and Anwar, 2005). Oral route is the most widely used route of administration for this drug. Recently, another alternative route has been explored for its potential beneficiary effect over the oral route. Promethazine $\mathrm{HCl}$ transport test was conducted to determine its abillity to penetrate skin. Analysis of the amount of promethazine $\mathrm{HCl}$ penetrated into the blood can be compared with determination of the amount of Promethazine $\mathrm{HCl}$ dissolved in phosphate buffer saline $\mathrm{pH}$ 7.4. Assay of Promethazine $\mathrm{HCl}$ in phosphate buffer saline $\mathrm{pH} 7.4$ can be useful to measure the amount of promethazine $\mathrm{HCl}$ included in the penetration study from the system.

The purpose of development and validation of analytical methods is to ensure that a suitable method for analysis of a particular analyte is specific, accurate and precise. Main purpose of this study is to validate the experimental conditions and parameters to be followed in the determination of Promethazine $\mathrm{HCl}$ in phosphate buffer saline $\mathrm{pH} 7.4$.

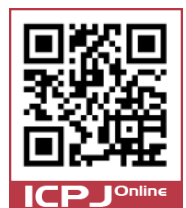

\section{MATERIALS AND METHODS}

\section{Chemicals and reagents}

Promethazine $\mathrm{HCl}$ working standard was a generous gift from Dong Gang City Hong Da Pharamceutical Co. LTD (Batch No. 110802; Exp. date- $4^{\text {th }}$ August 2015) from PT Berlico Mulia Farma, Sleman, Indonesia. Sodium dihydrogen phosphate, sodium chloride, potassium dihydrogen phosphate and all other chemicals were of analytical grade.

\section{Instrument}

UV-Vis spectrophotometer (Genesys 10S) and (Hitachi U 1800), Analytical Scales (AdvenC 2140), pH meter (Hanna HI 8314).

Preparation of phosphate buffer saline $\mathrm{pH} 7.4$

Phosphate buffer saline $\mathrm{pH} 7.4$ solution $1000 \mathrm{ml}$ was prepared by mixing $2.86 \mathrm{~g} \mathrm{NaH}_{2} \mathrm{PO}_{4}$ and $0.2 \mathrm{~g} \mathrm{KH}_{2} \mathrm{PO}_{4}$ in distilled water. 8 grams $\mathrm{NaCl}$ was added to the mixture. Solution was stirred with a stirrer and the $\mathrm{pH}$ of the solution was adjusted to 7.4 with the addition of a suitable buffer component (Nugroho, 2004).

Determination of the maximum wavelength of promethazine $\mathrm{HCl}$ in phosphate buffer saline $\mathrm{pH} 7.4$

Stock solution of Promethazine $\mathrm{HCl}$ in phosphate buffer saline $\mathrm{pH} 7.4$ was made by carefully measuring approximately $100.0 \mathrm{mg}$ of promethazine $\mathrm{HCl}$ and dissolving it in phosphate buffer saline $\mathrm{pH} 7.4$ in a $200.0 \mathrm{ml}$ volumetric flask. $10.0 \mathrm{ml}$ of the stock solution was filled into spectrophotometer cuvette and scanned over wavelength range of $200-550 \mathrm{~nm}$. The maximum wavelength of promethazine $\mathrm{HCl}$ in phosphate buffer saline $\mathrm{pH} 7.4$ were found is $251 \mathrm{~nm}$.

Validation of the assay method of promethazine $\mathrm{HCl}$ Linearity is the ability of the analysis procedure for obtaining the results of the experiment are directly proportional to the concentration of analyte in the sample (ICH, 1996). This parameter is a measure of how well the calibration curve that connects between the response $(y)$ and concentration $(\mathrm{x})$. Linearity is measured by a single 


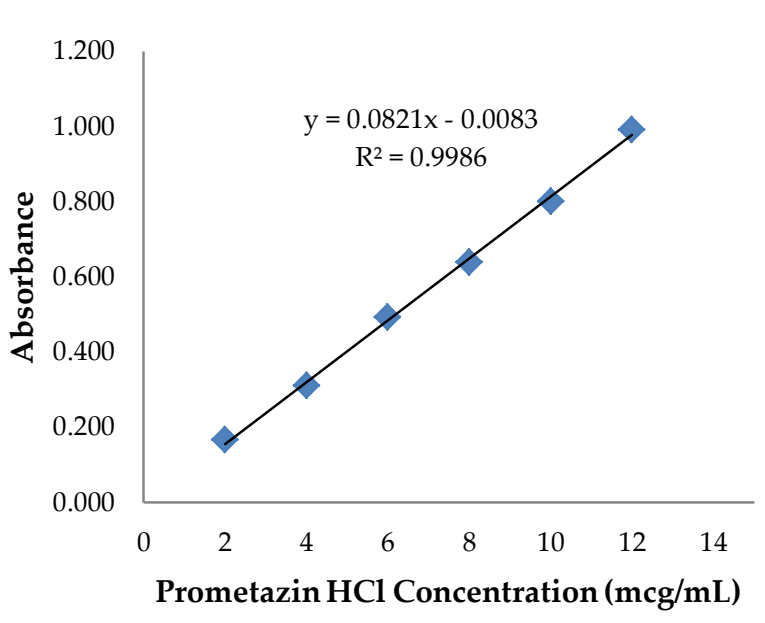

Figure 1: Graphical representation of linearity.

measurement at different concentrations and then determined the value of the slope and intercept and also correlation coefficient. Linearity test performed at a concentration of 0.125 to $12 \mathrm{~lm} / \mathrm{ml}$. Results from absorbance measurements at various concentrations were obtained value of $\mathrm{r}=0.9996$, proving the value of good linearity as approaching a value of 1 .

Linear regression equation of the standard curve shown in the equation is $Y=0.08 X+0.002$. Accuracy is the closeness of test results between the results obtained with the true value (true value) or the value of the reference. It describes the systematic error of the measurement results. Accuracy of the method was determined by measuring the concentration of promethazine $\mathrm{HCl}$ with $6.0 \mu \mathrm{g} / \mathrm{ml}$ of dilution of the stock solution in phosphate buffer saline $\mathrm{pH} 7.4$ in 9 samples solution. The obtained values of recovery studies were in the range of $98.7-103.6 \%$ which indicates the accuracy of the proposed method. ICH demands that 'a good accuracy value' should be in the range of $95-105 \%$ of the true value.

Intermediate precision values were determined by testing the samples in different days, different analysts, and using different equipments. According to the International conference of Harmonisation (ICH) (1996), a good value any precision measurement of a sample has a value of RSD not more than $2 \%$. Precision was determined by measuring the levels of promethazine $\mathrm{HCl}$ with concentration $6.0 \mathrm{mg} / \mathrm{ml}$ of dilution of the parent solution in phosphate buffer saline $\mathrm{pH} 7.4$ were analyzed 6 times. Precision was indicated in the coefficient of variation. The resulting intermediate precision values are as follows $1.51 \%$ and $1.54 \%$

\section{RESULTS AND DISCUSSION}

The analytical method development and validation for the Promethazine $\mathrm{HCl}$ in phosphate buffer saline $\mathrm{pH} 7.4$ was carried out. The linearity calibration curve (Figure 1) shows linear response over the range of concentration used. The precision data shows that the reproducibility of the assay procedure was satisfactory. The accuracy of the method was determined by recovery studies that was carried out by percentage recovery calculation. The robustness of the method was determined by analyzing the same sample under different laboratory, by different analyst and using operational and environmental conditions; the degree of reproducibility shows results are within their limit (Table 1-4).
Table 1: Data for method precision test.

\begin{tabular}{cccc}
\hline $\begin{array}{c}\text { Sample Conc. } \\
(\mu \mathrm{g} / \mathrm{mL})\end{array}$ & $\begin{array}{c}\text { Number of } \\
\text { Measurement }\end{array}$ & Absorbance & $\begin{array}{c}\text { Relative Std } \\
\text { Deviation }\end{array}$ \\
\hline & 1 & 0.48 & \\
& 2 & 0.492 & \\
6.0 & 3 & 0.482 & $1.50 \%$ \\
& 4 & 0.485 & \\
& 5 & 0.492 & \\
\hline
\end{tabular}

Table 2: Data for linearity test.

\begin{tabular}{cccc}
\hline $\begin{array}{c}\text { S1 } \\
\text { No. }\end{array}$ & $\begin{array}{c}\text { Promethazine HCl } \\
\text { Conc. }(\mu \mathrm{g} / \mathrm{mL})\end{array}$ & Absorbance & $\begin{array}{c}\text { Correlation } \\
\text { Coefficient }\end{array}$ \\
\hline 1 & 2 & 0.165 & \\
2 & 4 & 0.311 & \\
3 & 6 & 0.492 & 0.999 \\
4 & 8 & 0.638 & \\
5 & 10 & 0.801 & \\
\hline
\end{tabular}

Table 3: Data for accuracy test.

\begin{tabular}{|c|c|c|c|c|c|}
\hline 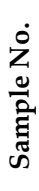 & 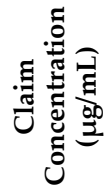 & 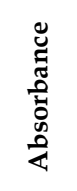 & 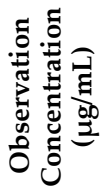 & 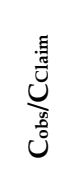 & 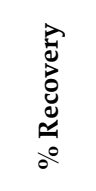 \\
\hline 1 & 6.0 & 0.510 & 6.031 & 1.005 & $100.5 \%$ \\
\hline 2 & 6.0 & 0.501 & 5.923 & 0.987 & $98.7 \%$ \\
\hline 3 & 6.0 & 0.518 & 6.136 & 1.022 & $102.2 \%$ \\
\hline 4 & 6.0 & 0.510 & 6.037 & 1.006 & $100.6 \%$ \\
\hline 5 & 6.0 & 0.519 & 6.143 & 1.024 & $102.4 \%$ \\
\hline 6 & 6.0 & 0.502 & 5.949 & 0.989 & $98.9 \%$ \\
\hline 7 & 6.0 & 0.525 & 6.225 & 1.036 & $103.6 \%$ \\
\hline 8 & 6.0 & 0.509 & 6.026 & 1.004 & $100.4 \%$ \\
\hline 9 & 6.0 & 0.510 & 6.030 & 1.006 & $100.6 \%$ \\
\hline
\end{tabular}

Table 4: Data for intermediate precision.

\begin{tabular}{lc}
\hline Variable Parameters & $\begin{array}{c}\text { Coefficient of } \\
\text { variation (\%) }\end{array}$ \\
\hline Analyst -1 & 1.59 \\
Analyst -2 & 1.68 \\
Equipment -1 (UV-Vis Spectrophotometer & 1.64 \\
Model Genyesis 10) & \\
Equipment -2 (UV-Vis Spectrophotometer & 1.82 \\
Model Hitachi U 1800) & 1.51 \\
Day -1 & 1.54 \\
Day -2 & \\
\hline
\end{tabular}

\section{CONCLUSION}

From the above data it can be concluded that all validation parameters (like methode precision, accuracy, linearity) met the predetermined acceptance criteria.

\section{REFERENCES}

Anonymous. (1996).Vlidation Of Analytical Procedures: Text and Methodology Q2 (R1). International conference of Harmonisation.

Anonymous (2007). British National Formulary London, BMJ Publishing Group Ltd RPS Publishing. 54.

Alam, M. S., Naqvi, A.Z., Kabir-ud-Din. (2007). "Influence of organic additives on the clouding phenomena of promethazine hydrochloride solutions." Colloid Polym Sci 285: 1573-1579. [DOI]

Nugroho, A.K., Li, G.L.,Danhof, M., and Bouwstra, J.(2004). “Transdermal Iontophoresis of Rotigotine Across Human Stratum Corneum in Vitro: Influence of $\mathrm{pH}$ and $\mathrm{NaCl}$ Concentration".Pharm.Res.21:844-850. [DOI]

Saif, M. J. dan J. Anwar (2005). "A new spectrophotometric method for the determination of promethazine- $\mathrm{HCl}$ from pure and pharmaceutical preparations." Talanta 67: 869-872. [DOI] 